ВИРУСЫ И КЛЕТКА

\title{
Aromatic thiosemicarbazones, their antiviral action and interferon. 1. The decreasing of adenovirus type 1 resistance against interferon by methisazone in vitro
}

\author{
Yuriy V. Patskovsky*, Emma N. Negrebetskaya, Alexandra A. Chernomaz ${ }^{1}$, \\ Tamara P. Voloshchuk, Eugeniy L. Rubashevsky, Oleg E. Kitam, \\ Mikhail I. Tereshchenko, Lidiya N. Nosach, Anatoliy I. Potopalsky \\ Institute of Molecular Biology and Genetics of the National Academy of Sciences of Ukraine \\ 150 Zabolotnogo str., Kyiv 252143, Ukraine \\ 'Zabolotnogo Institute of Microbiology and Virology of the National Academy of Sciences of Ukraine \\ 154 Zabolotnogo str., Kyiv 252143, Ukraine
}

\begin{abstract}
The mechanism of N-methyl-izatin-thiocarbazone (methisazone, MeIBT) antiviral activity has been studied on Adl-infected HEp2 and HeLa cells. MeIBT did not induce interferon and did not directly inhibit viral and cell translation. The adenoviral infection was not affected by recombinant human interferon $\alpha_{2}(r I F N)$. MeIBT showed antiviral effect in AdI-infected HEp2 or HeLa cells when rIFN had added to HeLa cells or in the period of interferon induction during virus infection (in $\mathrm{HEp} 2$ cells). In the presence of this compound, the E1A transcription was unchanged in infected cells as compared to untreated control, while early transcription was decreased, the beginning of viral replicution being retarded. Futhermore, the VAI RNA synthesis was also greatly suppressed. These effects were independent on interferon treatment and disappeared when MeIBT had been added during the late phase of virus growth cycle. Actually, MelBT can induce the delay of VAI RNA transcription promoting interferon antiviral effect.
\end{abstract}

Introduction. Methisazone ( $\mathrm{N}$-methyl-isatin- $\beta$-thiosemicarbazonc, $\mathrm{N}-\mathrm{MeIBT}$, MelBT) is a known antiviral drug studied earlier [1]. Izatizon is an original liquid form of MeIBT [2]. Both izatizon and MelBT possess a large spectrum of antiviral action, but izatizon is more effective (20-100 times higher than MeIBT) and demonstrates no toxic effects in therapeutical doses. Izatizon has been shown as an antiviral agent against poxviruses, herpesviruses, enteroviruses, influenza viruses A and B, etc. After optimal schemes of drug application, $100 \%$ curability was reported. So, the antiviral action of both MelBT and izatizon in vitro is identical [2].

The methisazone directed mechanism of cell defence is not known. Earlier published data demonstrate that MeIBT reduces the late post-replicative protein synthesis in virus-infected cells [3-6]. In the presence of this compound, a disruption of polysomes in vaccinia virus-infected cells has been also observed [7]. However, MeIBT induced no effect on in vitro translation [8 ]. It inhibited different DNA- and RNA-viruses [9]. The antiviral effect has been observed by treating the adenovirus-infected cells with MeIBT during the early phase of

FCorrespondence address.

(C) YU, Y. PATSKOVSKY, E. N. NEGREBETSKAYA, A. A. CHERNOMAZ, F. P. VOLOSHCHUK,

E. L. RLBASHEVSKY, O. E. KITAM, M. I. TERESHCHENKO, L. N. NOSACH, A. I. POTOPALSKY, 1990 
infection [10]. MeYBT also showed a slight suppressive action on RNAsynthesis [8]. Early studies have not detected the target of methisazone action in virus-infected cells. The activity of MeIBT against vaccinia virus was disappeared when cell transcription had been blocked by actinomycin D [4]. So, MeIBT cannot provide antiviral action without cell transcription. Moreover, whereas the existence of MeIBT-dependent and MeIBT-resistant mutants of vaccinia virus has been also reported [11], it is likely some viral gene/protein are methisazone targets, the latter being cooperated with a cellular gene (or genes).

Here we demonstrate that MeIBT is capable to reduce a viral defence against interferon antiviral action. Since MeIBT does not inhibit the adenoviral infection without interferon, interferon is a cellular compound necessary for methisazone directed cell defence mechanism.

Materials and Methods.MeIB' $T$ was synthesized as described previously (see [21). To test its action, the compound was dissolved in dimethyl sulfoxide (or in mixture DMSO:PEG400, 1:3, v/v ), stock concentration being 10-100 $\mathrm{mM}$; it was added to culture medium after virus absorption at different final concentrations $(0.001-50 \mathrm{mM})$. The final concentration of each solvent was not higher than $0.5 \%$. No toxic effects of solvents were observed up to $2 \%$ concentration.

C e l l s (HeLa and HEp2) were grown in the minimal essential Eagle medium supplemented with $10 \%$ fetal calf serum, $1.2 \mathrm{mM}$ glutamine and 0.2 $\%$ sodium bicarbonate, and a mixture of penicillin:streptomycin (up to 100 units $/ \mathrm{ml}: 40 \mathrm{mg} / 1$ ). The cells were infected with human adenoviruses - Ad H1 $3 \mathrm{H} 10$ (Ad1) and Ad H2 (Ad2) with a moiety of infection 5 PFU per cell. After incubation at $37{ }^{\circ} \mathrm{C}$, the Ad-infected cells were microscopically tested, washed by PBS, frozen at $-70^{\circ} \mathrm{C}$ and kept until futher studies.

I.nterferon enzyme im $m$ un o as s a y. Polychlorvynil plates (Titertek Immuno Assay-Plate, «Flow Laboratory») were used. Polyclonal anti-IFN antibodies were obtained from Research Institute of Hyperpure Biopreparations (St. Petersburg, Russian Federation). They were dissolved $(5 \mathrm{mg} / \mathrm{ml})$ and absorbed on the plates in $0.1 \mathrm{M}$ sodium carbonate-bicarbonate buffer, $\mathrm{pH} 9.6$, during $24 \mathrm{~h}$ at $45^{\circ} \mathrm{C}$. Free binding sites were blocked by $0.1 \%$ bovine serum albumin (BSA) in the same buffer $\left(1 \mathrm{~h}, 37{ }^{\circ} \mathrm{C}\right)$. Standard IFN $c_{2}$ (N. F. Gamaleya Epidemiology and Immunology Institute, Moscow) and tested probes were added in the PBST-BSA-0.1 buffer (solution containing $0.01 \mathrm{M} \mathrm{K}$-phosphate, $0.15 \mathrm{M} \mathrm{NaCl}, 1 \mathrm{mM} \mathrm{MgCl}$, and $0.05 \%$ Tween 20 , $0.1 \% \mathrm{BSA}, \mathrm{pH} 7.0,100 \mathrm{ml}, 1 \mathrm{~h}, 37^{\circ} \mathrm{C}$ ). Then the conjugate (at the dilution $1: 400,100 \mathrm{ml}$ ) was added, the probes being incubated $1 \mathrm{~h}$ at $37{ }^{\circ} \mathrm{C}$. Finally, the fluorogenic substrate $(0.01 \%$ water solution of 4-methylumbellipheryl- $\beta$ D-galactoside, $100 \mathrm{ml})$ was added, and after $2 \mathrm{~h}\left(37{ }^{\circ} \mathrm{C}\right)$ the reaction was stopped by adding $0.1 \mathrm{M} \mathrm{NaOH}$-glycine buffer, $\mathrm{pH} 10.3(100 \mathrm{ml})$. The fluorescence of probes was measured using Hitachi-850 spectrofluorometer (exitation $360 \mathrm{~nm}$, emission $450 \mathrm{~nm}$ ). After each step of incubation, microplates were washed 3 times by PBST buffer at room temperature. The conjugate of anti-IFN $\alpha_{2}$ monoclonal antibodies with $\beta$-galactosidase was obtained according to protocol of Boehringer Mannheim Biochemica Co.

The viral protein imm uno as s a y. The antiserum against Ad6 was oblained by intramuscular immunization of rabbits. The purification of the hexon Adl was provided by hydrophobic and ion exchange chromatography on the columns with buthyl-toyopearl («Toyosoda») and DEAE-Trisacryl («Pharmacia»). The purified hexon Ad1 was used for the performance of calibration curve.

The sandwich ELISA modification in polystyrol plates («Linbro») was used. Monoclonal antibodies against hexon Aål were dissolved $(10 \mathrm{mg} / \mathrm{ml})$ and 
absorbed on the plates as earlier (see upper). Then the plates were washed 3 times by PBST buffer and incubated in PBS (with $1 \%$ BSA) ( $30 \mathrm{~min}, 37{ }^{\circ} \mathrm{C}$ ). The cell lysates $(1: 10,100 \mathrm{ml})$ in PBST buffer were added $\left(1 \mathrm{~h}, 37^{\circ} \mathrm{C}\right)$, the rabbit serum against $A d \mathrm{H} 6(100 \mathrm{ml})$ was added and incubated $\left(1 \mathrm{~h}, 37^{\circ} \mathrm{C}\right)$. After washing, the HRP-conjugated goat antibodies against rabbit IgG (N. F. Gamaleya Epidemiology and Immunology Institute, Moscow) were diluted (1:100) and added (100 ml) too. After incubation during $1 \mathrm{~h}$ at $37^{\circ} \mathrm{C} \mathrm{HPR}$ activity was determined by adding of hydrogen peroxide (up to $0.015 \%$ ) and o-phenylendiamine (up to $0.4 \mathrm{mg} / \mathrm{ml}$ ) in $0.1 \mathrm{M}$ phosphate-citrate buffer, $\mathrm{pH}$ 5.0. The reaction was stopped by adding of $4 \mathrm{~N} \mathrm{H}_{2} \mathrm{SO}_{4}(50 \mathrm{ml})$. The optical densities of probes are measured at $490 \mathrm{~nm}$ using Dynatech MR700 photometer.

$D N A$ c $l$ o $n$ in $g$. DNA Ad2 was extracted according to [12]. Ad2 DBP-containing fragment (nt 23767 to $24103 /$ Sau3A sites/) was excised from $p A d R 4.3$ plasmid constructed by cloning of $E c o R I$ B-fragment (nt 21338 to 25633) from total Ad2 DNA in the EcoRI sitc of plasmid $p U C 19$. Then the 336 bp DBP-fragment was cloned in the BamHI site of $p U C 19(p D B P 0.3)$.

To clone VAI RNA gene, the HindIII B-fragment (nt 6231 to 11555) Ad2 DNA was excised and cloned in the HindIII site of $p U C 19$ (pAdH5.3). On the second stage, the AluI 548 bp fragment was extracted and cloned in the SmaI site of $p U C 19$ ( $p V A 1548$ ). On the third stage, the plasmid $p V A 224$ was obtaincd (nt $10255 / A l u I$ site/ to $10479 / X b a l$ site/) by removing $X$ bal-fragment from plA1548.

To test ElA transcription, the synthetic oligonucleotide probe was synthesized ( $\mathrm{nt} 831$ to 853 of $\mathrm{Ad} 2$ ).

$H$ ybridization procedures. RNA preparations from infected cells were extracted as described [13]. VAI RNA was purified according to $O$ :Malley et al. [14]. The DNA probes were labelled by nick-translation Promega kit with $\alpha_{-}^{32} \mathrm{P}$-dCTP to a specific radioactivity of $(1-5) \cdot 10^{8} \mathrm{cpm} / \mathrm{mg}$ of DNA. Electrophoresis of the denatured RNA samples in $2 \%$ agarose gels containing $2 \%$ formaldehyde, blot-transfer to Hybond $\mathrm{N}$ membrane, DNADNA and DNA-RNA hybridization to the ${ }^{32} \mathrm{P}$-labelled DNA probes were performed as described previously [15]. Filters were dissected and radioactivity of hybridized probes was detected according to Cerencov program.

Results. The cytotoxicity of MeIBT was usually observed with drug concentration above $40 \mathrm{mM}$. The lower concentrations were inhibiting for the viral protein synthesis in a dose-dependent manner as expected from earlier results [10]. The sensitivity of Adl to MelBT in vitro action was determined by immunoassay method. Our data concerning drugs have been shown no differences between MeIBT and izatizon in vitro action. The decreasing of viral hexon synthesis was observed in MeIBT-treated Ad1-infected HEp2 cells (Fig. $1, a)$. The recombinant human interferon $\alpha_{2}$ (rIFN) did not damage hexon
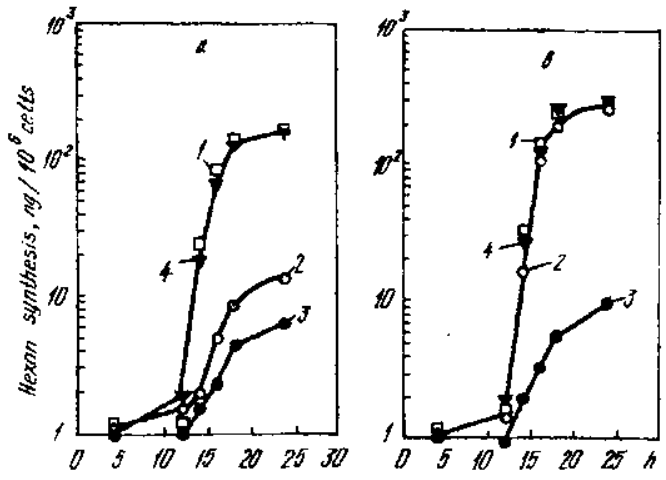

Fig. 1. The lcvel of hexon synthesis in Adl-infected HEp2 cells $(a)$ and HeLa cells (b) during virus growth cycle. MeIBT (2.5 $m M)$ and $\operatorname{rIFN}(1000 \mathrm{U} / \mathrm{ml})$ were supplemented to the culture medium at $\mathrm{l} \mathrm{h}$ p. i. Hexon assay were performed in the extracts of infected cells $\left(10^{\circ}\right.$ cells in each variant) frozen at $-70{ }^{\circ} \mathrm{C}$. Values represent the mean of 3 determinations. 1 - Control; 2 - MeIBT; $3-$ MelBT + rIFN; $4-$ rIFN 
synthesis, however MeIBT antiviral effect increased in the presence of rIFN. On the other hand, the level of hexon accumulation did not decrease in MeIBT-treated Adl-infected HeLa cells as compared to untreated culture (Fig.1,b). The riFN did not also inhibit the adenoviral infection in HeLa cells. However, in the presence of both MeIBT and rIFN, the antiviral effect appeared again (Fig. $1, b$ ). Hexon accumulation in adenovirus-infected cells was sharply inhibited when the addition of MeIBT $(+$ rIFN) is delayed until $8 \mathrm{~h}$ post infection (p. i.). Increasing amounts of viral hexon appeared when addition of the drug is delayed beyond this time (not shown). Since adenoviruses are not sensitive to interferon antiviral effects, it is likely the antiviral activity of MelBT is due to activation of both early viral functions and interferon expression.

In the absence of MeIBT, Ad1 stimulated interferon expression in HEp2 cells beginning from the 2nd $\mathrm{h}$ p. i. (Fig. 2, a). The maximum of interferon

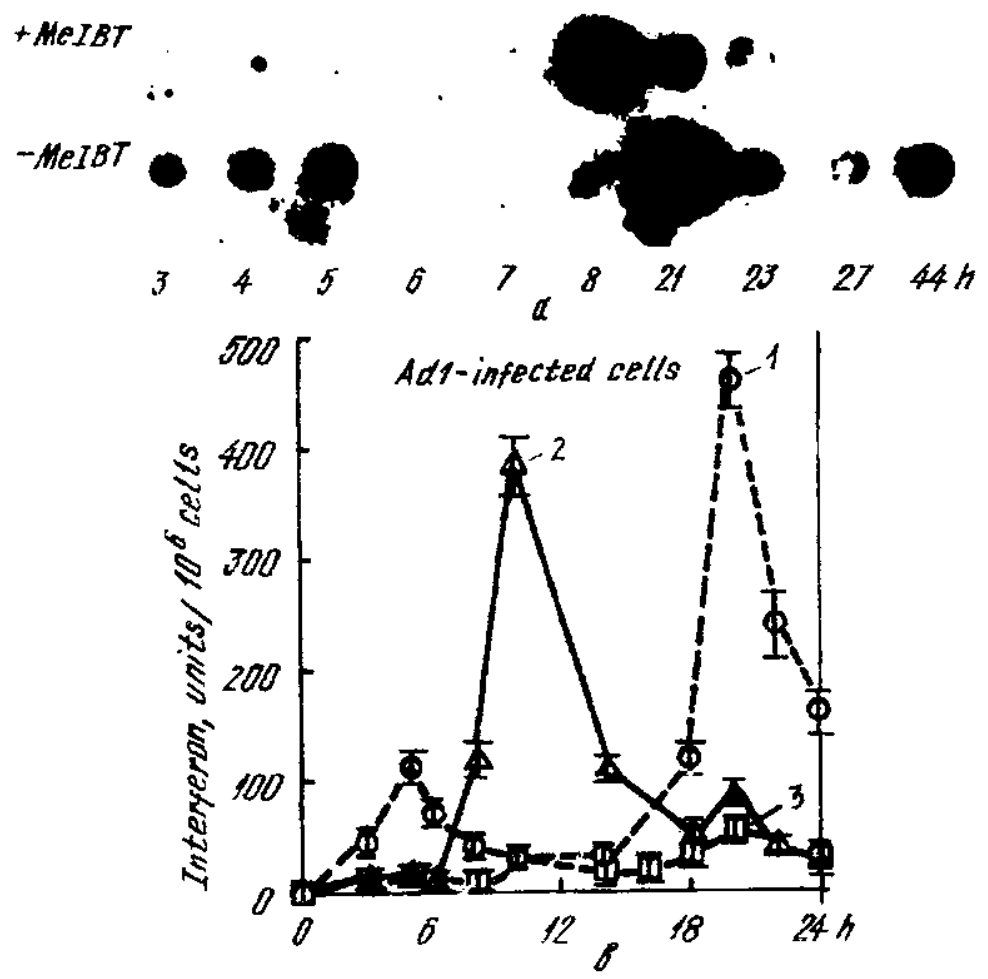

Fig. 2. The expression of interferon $\alpha_{2}$ in $\Lambda$ dl-infected HEp2 ceils. MeIBT (2.5 mM) was supplemented to the culture medium at 1 st $\mathrm{h}$ post infection; $a$ - DNA-RNA dot-hybridization of 1otal RNA of Adl-infected cells $\left(10^{5}\right.$ cells in each variant) was performed with nick-translated probe pIF226; $b$ - interferon $\alpha_{2}$ was determined in culture media by immunofluorescence assay during virus growth cycle ( 1 - HEp2, control; $2-\mathrm{HEp2,} \mathrm{MeIBT;} 3$ - HeLa, MeIBT). Values represent the mean of 3 determinations

synthesis was observed at the 5 th $\mathrm{h}$. Later the level of interferon increased, and the second maximum of interferon appeared at the 20-21 th h p. i. After $40 \mathrm{~h}$, the third maximum was also revealed. Existence of more than one maximum of interferon induction shows the possibility of virus reinfection beyond each virus growth cycle (16-18 $\mathrm{h}$ in our experiments). The infective process developed completely on the third day. Almost all the cells were infected and aggregated. On the contrary, Adl induced tenfold lower interferon titer in HeLa cells as compared to HEp2 ones (Fig. 2,b). The same results have been also obtained with HeLa S3 cells and Vero cells (data not shown). The drop of interferon expression correlates to the absence of MeIBT antiviral action in virus-infected 
Cytotoxicity and antiadenoviral activity of drugs

\begin{tabular}{|c|c|c|c|c|}
\hline Drugs & Célls & $\mathrm{EC}_{50}{ }^{*}, \mathrm{mM}$ & $\mathrm{ID}_{50}{ }^{* *}, \quad \mathrm{mM}$ & $\mathrm{ID}_{50} / \mathrm{EC}_{50}$ \\
\hline MeIBT & HEp2 & 0.7 & 47.0 & 67 \\
\hline $\mathrm{MelBT}+\mathrm{rIFN}, 500 \mathrm{U} / \mathrm{ml}$ & HEp2 & 0.4 & 45.0 & 112 \\
\hline $\mathrm{MeIBT}+\mathrm{rIFN}, 1000 \mathrm{U} / \mathrm{ml}$ & HEp2 & 0.15 & 45.5 & 303 \\
\hline MeIBT+rIFN, $2000 \mathrm{U} / \mathrm{m} !$ & HEp2 & 0.1 & 47.5 & 475 \\
\hline Izatizon & HEp2 & 0.8 & 48.0 & 60 \\
\hline lzatizon+rlFN, $1000 \mathrm{U} / \mathrm{ml}$ & HEp2 & 0.13 & 47.0 & 361 \\
\hline MeIBT & HeLa & $N A^{* * *}$ & 47.5 & - \\
\hline $\mathrm{MelBT}+\mathrm{rlFN}, 1000 \mathrm{U} / \mathrm{ml}$ & $\mathrm{HeLa}$ & 0.2 & 46.0 & 230 \\
\hline Izatizon & Hela & NA. & 50.0 & - \\
\hline Izatizon+rIFN, $1000 \mathrm{U} / \mathrm{ml}$ & Hela & 0.2 & 47.0 & 235 \\
\hline
\end{tabular}

${ }^{*} \mathrm{EC}_{50}-$ concentration providing $50 \%$ inhibition of virus yield at the $24 \mathrm{th} \mathrm{h}$ p. $\mathrm{i}_{\text {.; }}{ }^{*}{ }^{*} \mathrm{ID}_{50}-$ concentration providing $50 \%$ inhibition of cell viability (measured by $\mathrm{NT}^{\prime} \mathrm{l}$-test); ${ }^{* * *} \mathrm{NA}-$ not affected.

HcLa ceils, and virus hexon synthesis was greatly reduced by simultaneously adding of rIFN and MeIBT (see Fig. $1, b$ and table).

MeIBT influcnced on the induction of interferon in Ad1-infected HEp2 cells (Fig. 2). The interferon expression being low until 8th $\mathrm{h}$ p. i. increased sharply after $8-9$ h p. i. and became further depressed after $12-14 \mathrm{~h} \mathrm{p}$. i. Another
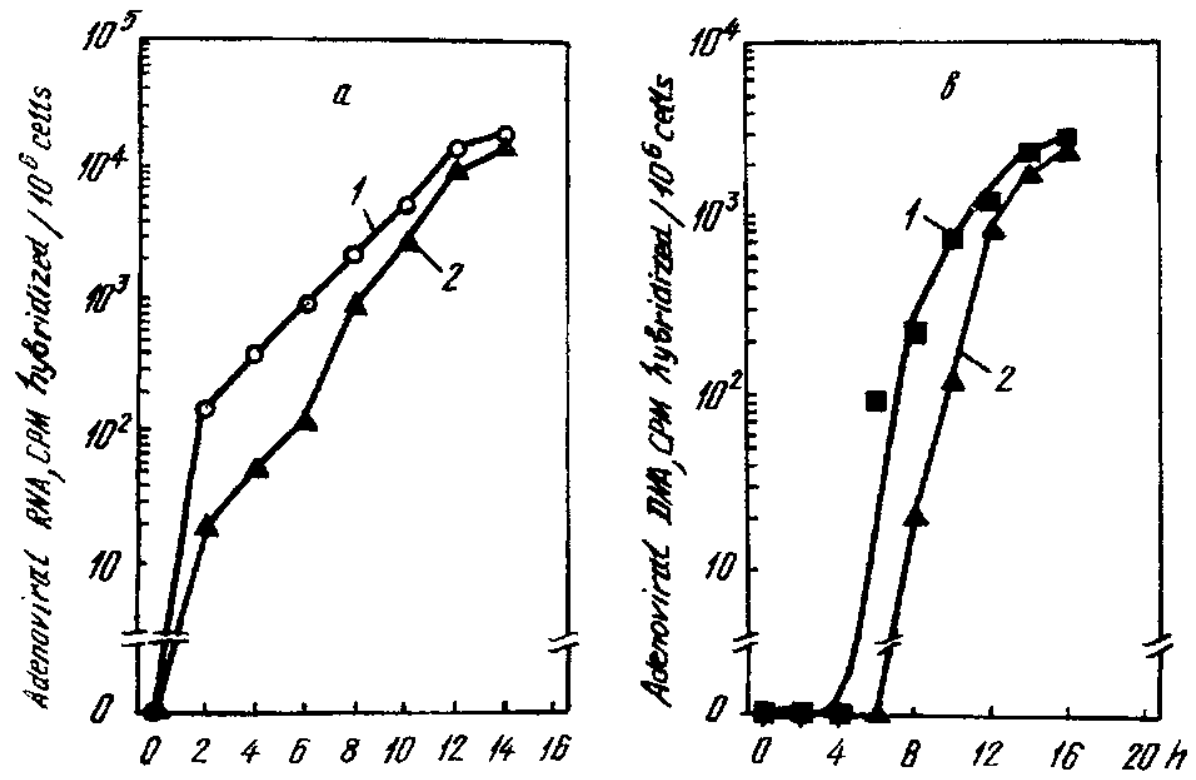

Fig. 3. MeIBT retards early transcription $(a)$ and viral replication $(b)$ in Adi-infectcd cells. The extracts of Ad1-infected MeIBT (2.5 mM)-treated and untreated HEp2 cells (106 ce!ls in each varian1) were hybridized with nick translated DNA Ad2. The radioactivity of dissected filters was measured according to Cerencov program. $1 \rightarrow$ Control; $2-$ MeIBT 
maxima of interferon synthesis were slight. The appearence of virus cylopathic effect was delayed. Since MelBT (as well as izatizon) does not induce any type of interferon in vitro and in vivo [2], and possesses no direct action on translation [8] we conclude that this compound might act on the early viral transcription resulting to be the modification of interferon expression in virus-infected cells.

The possible mechanism of MeIBT action makes predictions retarding the beginning ng of early viral transcription. Accordingly, we measured amounts of total viral RNA and viral DNA in extracts of with and without MeIBT-treatcd infected or uninfected cells (HeLa and HEp2) by dot-hybridization method. In control cells no hybridization signal has been detected. After infection the amounts of viral RNA greatly increased especially from the beginning of the late phase of virus growth cycle (Fig. 3,a). After MeIBT treatment the accumulation of early viral RNA was $7-10$ fold reduced (Fig. 3,a) as compared to untreated Adl-infected cells up to the 8th h p. i., and increased beyond this time. As found previously on the model of vaccinia virus-infected cells [8], the 50 per cent inhibition of transcription has been also observed during the late phase of virus growth in MelBT-treated culture. Moreover, the time of half-life of RNA transcripts was identical in MeIBT-treated and untreated cells [8]. The delay of viral transcription appeared if MeIBT had been added until $8 \mathrm{~h} \mathrm{p}$. i. and disappeared when MeIBT had been added later.

Earlier it has been shown that MeIBT does not inhibit vaccinia virus replication [5]. The equal amounts of adenoviral DNA were observed in MelBT-treated cells and in untreated ones only on the late infection phase (18 $\mathrm{h} \mathrm{p}$. i.). However, the analysis of Adl DNA accumulation during the virus
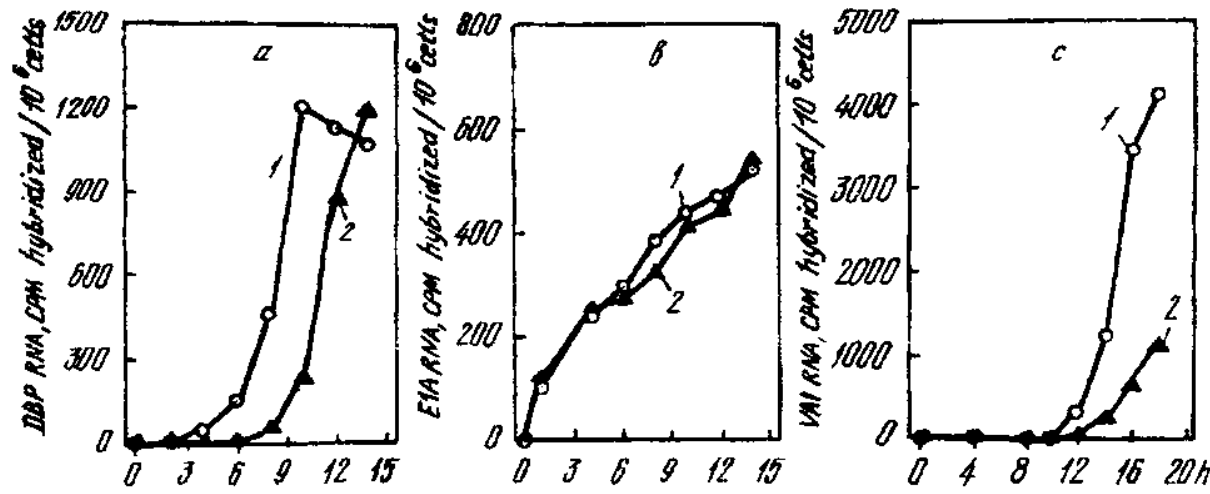

Fig 4. The accumulation of DBP- $(a)$, ElA- $(b)$, and VAI RNA- $(c)$ transcripts during virus growth cycle in Ad1-infected HEp2 cells. The extracts of Ad1-infected MeIBT (2.5 mM)-treated and untreated $\mathrm{HEp} 2$ cells $\left(10^{6}\right.$ cells in each variant) were hybridized with nick-translated DNA; $a-$ DNA-RNA dot probed with $p D B P 0.3 ; b-$ DNA-RNA dot-hybridization with synthetic oligonucleotide probe (E1A); $c$ - to test VAI RNA, the nick-translated probe $p V A 224$ was used; $I-$ Control; 2 - MeIBT

growth cycle has revealed that drug retards the beginning of viral DNA synthesis in Adl-infected cells as compared to untreated cells (Fig. 3, b). This effect was obtained when MeIBT has been added until 8 th $\mathrm{h}$ after infection, and disappeared when MeIBT has been added later. So, MeIBT cannot directly inhibit viral replication. Since the viral DNA-polymerase mRNA is transcribed from the early region of adenoviral genome [16], it is likely this effect of compound follows the delayed early transcription. 
In addition, the same effect of MeIBT was shown by testing DBP-gene transcription in Ad1-infected cells. Hence, the accumulation of DBP-transcripts was reduced in MelBT-treated cells as compared to untreated culture during $8-10$ h p. i. (Fig. 4, a).

To test whether MeIBT treatment influenced on the transcription of early Ad1 1A region (E1A), the amounts of ElA RNA were measured in Adl-infected cells during virus growth using dot-hybridization with polynucleotide kinasephosphorylated oligonucleotide probe. Our experimental data showed no influence of compound on E1A transcription (Fig. 4, b).

Since MeIBT depresses early transcription and viral replication in Ad1infected HEp2, HeLa, and HeLa S3 cells with and without interferon, it proves MeIBT functions to be interferon-independent.

Adenoviruses are relatively resistant to interferon challenge [14]. The loss of interferon antiviral activity is due to P1/eIF2 kinase inhibition by viral VAI RNA. In the presence of interferon and small quantities of dsRNA, the kinase can phosphorylate initiation factor eIF2 inducing polysomes disruption and blocking translation [14]. Earlier, the VAI RNA synthesis by RNA-polymerase III has been shown after viral replication beginning [16]. Since the viral DNA-synthesis was retarded in MeIBT-treated cells, we have proposed VAl RNA-gene transcription to decrease. To test the level of VAl RNA synthesis, the dot-hybridization has been used. Our data have been demonstrated VAI RNA accumulation to be retarded and reduced in MelBT-treated Adl-infccted HEp2 cells as compared to untreated Ad1-infected cells (Fig. 4, c). These data were completely confirmed by Northern analysis of VAI RNA (Fig. 5, a). The loss of VAI RNA was not observed when the addition of drug has been provided on the late phase of virus growth cycle (Fig. $5, b$ ). So, it is evident the antiviral agent does not directly suppress VAI RNA synthesis and RNA-polymerase III activity. The rIFN has also shown no effect on VAI RNA transcription (Fig. 5, b). Moreover, the drop of VAI RNA transcription was appeared in MeIBTtreated Ad1-infected HeLa cells (Fig. 5, c) when the adenoviral infection was MeIBT-resistant, and the Ad1 induced the low titer of interferon.

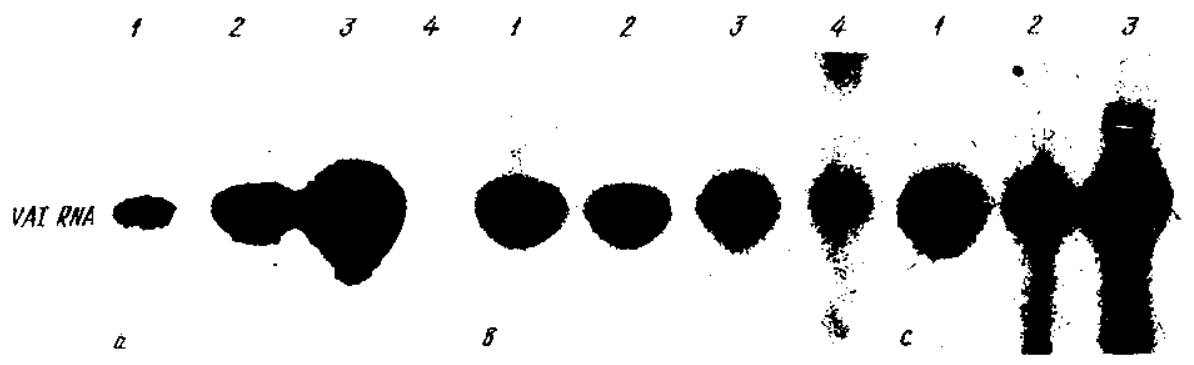

Fig. 5. MelBT effect on VAI RNA synthesis. The RNA of Adl-infected cells $\left(10^{\circ}\right.$ cells in each variant) was extracted at the 16th $\mathrm{h}$ p. i. and run in electrophoresis. VAI RNA analysis was provided by Northern blot probed with $p V A 224 ; a-$ VAI RNA of Ad1-infected HEp2 cells. 10 ng purified VAI RNA (line I) was presented. MeIBT (2.5 mM) was added (line 2) or not (line 3) in the culture medium at the 1 st $h$ p. $i$. The low molecular RNA of Adl-infected HEp2 cells (the 1 st $h$ p.i.) is also) presented (line 4);b-50 ng of purified VAI RNA was added (line 1 ). VAl RNA of Adl-infected untreated HEp2 cells (line 2), and VAI RNA of Adl-infected HEp2 cells when MeIBT (2.5 mM) and $\mathrm{rJFN}(1000 \mathrm{U} / \mathrm{mi})$ were simultaneously added at the $8 \mathrm{th} \mathrm{h}$ (line 3 ) and at the $1 \mathrm{st} \mathrm{h}$ (line 4) p. i; $c$ - VAI RNA analysis in Ad?-infected Hela cells. $50 \mathrm{ng}$ purified VAI RNA was run (line $/$ ). MeIBT (2.5 $\mathrm{mM}$ ) was added (line 2) or not (line 3) at the $1 \mathrm{st} \mathrm{h} \mathrm{p}$. i. 
Discussion. Our experimental data show that the main action of MeIBT is related with the delay of both early adenoviral transcription and adenoviral replication. Since MeIBT does not inhibit the viral protein synthesis without interferon and interferon does not inhibit viral infection without the drug, it is evident that MeIBT can suppress the viral defence against interferon action. Actually, interferon is the necessary cell compound participating in the MeIBT directed mechanism. How common is such a mechanism restoring interferon action? According to [14], the virus protection against interferon is dependent on VAI RNA which can inhibit interferon activated P1/eIF2 kinase. The virus defence against interferon action is developed when large amount of VAI RNA appear during the late phase of virus growth cycie. Since the level of VAI RNA synthesis is sharply reduced in MelBT-treated Adl-infected cells, a high concentration of interferon is capable to increase the initiation of factor eIF2 phosphorylation balloned by translation blocking. Moreover, the rate of translation was greatly stimulated in cell-free extracts from MelBT+interferontreated Ad1-infected cells when the purified eIF2 was added (data not shown).

The mode of MeIBT action described here may be appropriate for another DNA- and RNA-viruses. In addition, we can suggest about the correlation between the interferon-inducing ability of viruses and the antiviral effect of this compound. Moreover, some other MelBT-susceptible viruses [9] possess an analogous prolective mechanism against interferon action [17]. Besides, methisazone does not significantly prevent the production of viral antigen by cells already chronically infected with HIV-1. However, in the presence of IIFN, the compound (nontoxic concentrations) can reduce the yield of infective virus in this culture by $10-100$ fold.

The viral target of MeIBT is still unknown. Since the MelBT-resistant mutants of vaccinia virus has been obtained earlier [11], it is probable the existence of one virus gene/protein-target of MeIBT. Our experiment showed the delay of early transcription in MeIBT-treated Adl-infected cells, but the transcription of early region A1 was not significantly changed. A protein encoded in $\mathrm{E} 1 \mathrm{~A}$ region promotes the rapid onset of viral transcription. This phosphoprotein predicted from the sequence of its mRNA is to be 289 amino acids long (289 pp) and required to facilitate early transcription [18 ]. Moreover, it contains a zinc-binding region [19]. On the other hand, MeIBT is known as an effective chelating agent $\left[20 \mid\right.$ which binds preferentially cations $\mathrm{Zn}^{2+}$ and $\mathrm{Cu}^{2+}$. It is tempting to speculate that MeIBT might function by suppressing the 289 pp activity.

Acknowledgements. We thank Dr. Vitaly A. Kordyum for the providing of recombinant human interferon $\alpha_{2}, \beta$-galactosidase, and plasmid pIF226 containing the human interferon $\alpha_{2}$ gene. We thank also Dr. Anatoly G. Terientiev for the providing of fluorogenic substrate for interferon immunoassay, and Dr. Yelene K. Kiseleva for a gift of monoclonal antibodies against hexon Ad1. This work was partially supported by a grant from National Committee of Science and Technology, Ukraine (1.07.01/003).

Ю. В. Лацковський, Е. М. Негребецька, О. О. Уорномаз, Т. П. Волоицк, Є. Л. Рубаиевський, О. Е. Кітам, М. І. Тереценко, Л. М. Носач, А. І. Потопальський

Ароматичні тіосемікарбазони, іх антивірусна дія та інтерферон. 1. Зниження стійкості аденовірусу 1-го типу до інтерферону в присутності метисазону in vitro

\section{Резкоме}

Визиали мехапізм реалізацій антивірусного ефекту $N$-метил-ізатин-тіосемікарбазону (метисазону) на .моделі аденовірусної (аденовірус людини 1 muпу) інфекиї іn vitro. ІІоказано, иоо репродукція вірусу резистентна до рекомбінантного інтерферону $\alpha_{2}$ людини, а нетисазон пригнічуе вірусну інфекиію личе в присутності інтерферону - ендо- або ехзогенного. 
Тесмуванням синтезу вірусної ДНК та РНК, а також експресї окремих вірусних цеків менодани доп- $і$ Нозерн-гібридизачї встановлено, що метисазон затримуе транскрипцію "раниіх» ценіо аденовірусу. Це призводить до затримки початку реплікаиї вірусу і змениує кониентраиію VAI РНК. Оскільки кількість VАI РІК вияначае рівень стійкості аденовірусу до інтерферону, то, очевидно, що метисазон посилюе деструктивний өплив інтерферону на синтез вірусних білків.

Ю. В. Пацковский, Э. Н. Негребецкая, А. А. Черномаз, Т. П. Волоиук, Е. Л. Рубаиевский, О. Ј. Китам, М. И. Терещенко, Л. Н. Носач, А. И. Потопальский

Ароматические тиосемикарбазоны, их антивирусное дсйствие и интерферон. 1. Снижение устойчивости аденовируса 1-го типа к интерферону в присутствии метисазона in vitro

Рeзюме

Изучен механизм реализации антивирусного эффекта $N$-метил-изатин-тиосемикарбазона (метисазона) на модели аденовирусной (аденовирус человека l-го типа) инфекиии in vitro. Показано, что репродукиия вируса резистентна к рекомбинантному интерферону $\alpha_{2}$ человека, а

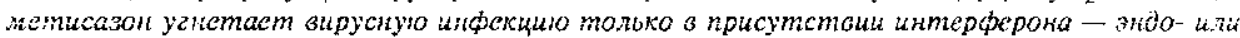
экзогенпого. Тестированием синтеза вирусной дНК. и РНК, а тахже экспрессии опоельных вирусных генов методами дот- и Нозерн-гибридизации установлено, что метисазон задерживает транскрипиию "ранних" генов аденовируса. 3то приводит к задержке начала репликации вируса и уменьиает концентрацию VAI РНК. Поскольку количество VАI РНК определяет уровень устойнивости аденовируса $\kappa$ интерферону, то, очезидно, ито метисазон усиливает деструктивное влияние интерферона на синтез вирусных белков.

\section{REFERENCES}

1. Bauer D. J. Clinical experience with the antiviral drug marboran (1-methyl-izatin-3thiosemicarbazone) // Ann. N. Y. Acad. Sci.-1965.-130, N 1.-P. 110-117.

2. Потопальский А. И., Лозюк Л. В., Миролюбова А. Н., Бесарабоз Б. Ф. Противовирусный, гротивоогухолевый и антилейкозньй препарат изатизон. - Киев: Наук. думка, $1991 .-192 \mathrm{c}$

3. Magee W. E. Bach M. K. Biochemical studies on the antiviral activities of the izatinthiosemicarbazone/! Ann. N. Y. Acad. Sci,-1965.-130, art. 1.-P. 80-91.

4. Appleyard G., Hume V. B. M., Wesfwood J. C. N. The effect of thiosemicarbazone on the growth of rabbit pox virus in tissue culture // Ibid. - P. 92-104.

5. Pennigton $T$. H. Izatin-thiosemicarbazone causes premature cessation of viccinia virus-induced late post-replicative polypeptide synthesis // J. Gen. Virol. $-1977 .-35$, N 3.-P. 567-571.

6. Prusoff W. H., Goz B. Potential mechanism of action of antiviral agents // Fed. Proc.-1973.— 32.-P. $1679-1687$.

7. Woodson $B$., Joklik $W . K$. Inibition of vaccinia virus multiplication by izatin- $\beta$-thiosemicarbazone // Proc. Nat. Acad. Sci. USA.-1965.- 54, N 3.-P. 946-951.

8. Cooper J. A., Moss B., Katz E. Inhibition of vaccinia virus late protein synthesis by izatin-brta-thiosemicarbazone: characterization and in vitro translation of viral mRNA// Virology.- 1979.-96, N 1.-P. 381-392.

9. Ievinson $W$. Inhibition of viruses, tumors and pathogenic microorganisms by izatin-thiosemicar bazone and other thiose micarbazones // Selective inhibitors of viral functions / Ed. W. $A$ Carter.-London: CRC press, 1973.-.P. 213-226.

10. Bauer D. J., Apostolov $K$. Adenovirus multiplication: inhibition by methisazone // Science.1965.-154, N 3750.-P. 796-797.

1!. Katz E., Margalith E., Winer $B$. The effect of izatin-1hiosemicarbazone (IBT)-related compounds on IBT-resistant and IBT-dependent mutants of vaccinia virus $/ / \mathrm{J}$. Gen. Virol. - 1974. -25, N2.-P. 239-244.

12. Robinson F. V., Yonghusbend H. B., Bellett A. V. D. A circular DNA-protein complex from adenoviruses // Virology.-1973. $\rightarrow 56$, N. 1.-P. 54-69.

13. Anderson C. W., Lewis J.B., Atkins J. F., Gesteland R. F. Celt-free synthesis of adenovirus 2 proteins programmed by fractionated messenger RNA: a comparison of polypeptide products and messenger RNA lengths // Proc. Nat. Acad. Sci. USA.-1974.-71, N 2.-P. 2756-2760.

14. O'Malley R. P., Mariano T. M., Siekierka J., Mathews M. B. A mechanism for the control of protein synthesis by adenovirus VA RNAI // Cell.-1986. -44, N 2.-P. 391-400.

15. Маниатис Т., Фрич Э., Сзмбрук Дж. Методы генетической инженерии. Молекулнрное клонирование.- М.: Мир, $1984 .-480$ с.

16. Weinmann $R$, Raskas H.J., Roeder $R$. G. Role of DNA dependent RNA polymerase II and III in transcription of the adenovirus genome late in productive infection // Proc. Nat. Acad. 
Sci. USA. - 1974.- 71, N 8.-P. 3426-3430.

17. Rice A. P., Kerr I. M. Interferon-mediated, dotble-stranded RNA-dependent protein kinase is inhibited in extracts from vaccinia-virus infected cells // J. Virol.-1984.-50, N 1.-P.229236.

18. D'Halluin J. C., Leclere $V$. The adenovirus E1A gere: immortalizating nuclear oncogene prototype // Bull. Inst. Pasteur. -1992. -90, N 1.-P. 45-65.

19. Culp J. S., Webster L. C., Friedman, D. J. The 289-amino acid E1A protein of adenovirus binds zinc in a region that important for transactivation // Proc. Nat. Acad. Sci. USA.-1988.-85, N 17. - P. 6450-6454.

20. Sadler $P . W$. Antiviral chemotherapy with izatin-beta-thiosemicarbazone and its derivatives // Ann. N. Y. Acad. Sci.-1965-130, art. 1.-P. $71-79$.

LiDk 547.94

Received 25.05.95 